\title{
Social Integration of Immigrants within the Linguistically Diverse Workplace: A Systematic Review
}

\author{
Vibha Kaushik ${ }^{a^{*}}$, Christine A. Walsh ${ }^{b}$, Diana Haefele \\ a Faculty of Social Work, University of Calgary, Canada \\ b Faculty of Social Work, University of Calgary, Canada \\ c Faculty of Information and Media Studies, Western University, Canada \\ *Corresponding author (vkaushik@ucalgary.ca)
}

\section{ART T C LE INF O}

Received: 31-08-2015

Accepted: 08-01-2016

Available online: 20-01-2016

Keywords:

Immigrants;

Language;

Linguistic diversity;

Social integration;

Workplace.

JEL Classification:

F22; J70; J15; M14.

\begin{abstract}
A B S T R A C T
Due to international migration, a large number of workplaces are becoming linguistically diverse. This creates challenges for the workplace integration of immigrants and increases the risk of their social exclusion. A systematic review was conducted to determine the effects of linguistic diversity on social integration of immigrants within the workplace. Articles were identified by reviewing abstracts in electronic databases using keywords related to linguistic diversity, social integration, immigrants and workplace. The search yielded ten peer reviewed articles, published in English, between 2000 and 2014. Information was extracted and synthesized from both quantitative and qualitative studies. The studies were found to be concerned on: (1) social integration or social inclusion/exclusion, (2) social interaction and inter-group perception, and (3) accent discrimination. Smooth social and professional assimilation and the equality of opportunities for the immigrants were considered as the determining factors of their complete social integration in the workplace. Most studies in this review established a connection between social integration and local language skills; some indicated that racial discrimination and ethnicity based stereotyping contributes to social exclusion of immigrants, particularly when the studies involved visible minorities. The review enhances our understanding of challenges of complete social integration faced by immigrants and reinforces the need to invest in policies and program aimed at preventing marginalization of immigrants. Due to limited number of studies identified by this review and the variation in findings, further research is necessary to investigate the role of linguistic diversity in the workplace integration of immigrants in immigrant receiving countries.
\end{abstract}

(C) 2015 The Authors. This is an open access article under the terms of the Creative Commons Attribution License 4.0, which allows use, distribution and reproduction in any medium, provided the original work is properly cited.

DOI: http://dx.doi.org/10.18533/rss.v1i1.5

\subsection{Introduction}

Workplace integration of immigrants is complex and multifactorial. One factor which has been identified as a pre-requisite for their successful assimilation and growth within an organization, and to avoid marginalization is their ability to communicate freely in the language of the workplace. As Oliver Sacks (1989) eloquently stated:

... to be defective in language, for a human being, is one of the most desperate of calamities, for it is only through language that we enter fully into our human estate and culture, communicate freely with our 
fellows, acquire and share information. If we cannot do this, we will be bizarrely disabled and cut off whatever our desires, or endeavors, or native capacities. (p. 8)

Often an immigrant, who arrives in a new land with only a limited proficiency of the language of the destination, is unable to communicate freely with fellow workers and is consequently considered incapable of high professional competence (Vaara, Tienari, Piekkari, \& Säntti, 2005). Even Aristotle declared that if a person doesn't say anything, he is very much like a vegetable (Charles, Gill, \& Scaltas, 1994). Perhaps Aristotle's blatant declaration has little to do with a person's innate intelligence, instead it illustrates that if a person cannot communicate freely, he or she becomes withdrawn and cannot become involved in social interactions.

Some researchers identify language as a tool that facilitates the acquisition and transmission of information through social interaction within one's surroundings (Dhir \& Góké-Paríolá, 2002; Feely \& Harzing, 2003). Although researchers may hold fundamentally different views on the specific role of language in social interaction, most would agree that language provides an essential link to knowledge (Berger \& Luckmann, 1966; Chomsky, 1996; Grünhage-Monetti et al., 2003; Wittgenstein, 1922). Language and knowledge are also linked with power (Clegg, 1989); therefore, it has been emphasized that a lack of dominant language proficiency not only compromises access to better economic opportunities and social resources, but also hinders immigrants from participating in the power structure of the host society (Dustmann \& Fabbri, 2003; Shields \& WheatleyPrice, 2002).

Language is also conceived to be a socio-cultural resource used to achieve and express cultural and social notions of behavior (Bourdieu, 1991, 2004). The social dimension to language has implications for the understanding of immigrant integration within linguistically diverse workplaces. Immigrant workers who master the local language have access to a range of formal and informal communication channels, which enables them to be engaged in social bonding across the organization. However, individuals having lack of or weak local language competence repeatedly find themselves isolated from information networks and decision-making processes (Marschan-Piekkaria et al., 1999b).

The current body of literature presents several limitations. The majority of research efforts to date are directed at diagnosing the adverse effects of language barriers on the organizations (Feely \& Harzing, 2003; MarschanPiekkari et al., 1999a) and its members (Bergman et al., 2008; Boyd \& Cao, 2009, 2009; Charles \& MarschanPiekkari, 2002) while simultaneously looking for measures to mitigate such barriers through staffing and training (Gibson \& Hodgetts, 1991; Luo \& Shenkar, 2006; Von Glinow, 1988). However, the existing literature provides an incomplete understanding of the social aspects of communicative practices emerging between the mainstream employees, who are the native speakers of the local language, and the immigrant employees, who are not the native speakers of the local language, within a linguistically diverse workplace. Further, in the existing knowledge base, the effects of linguistic diversity on social integration of immigrants within the workplace have not been adequately evaluated. Thus, to address this gap in the current body of literature, a systemic review was undertaken. The purpose of the systematic review was to determine the effects of linguistic diversity on social integration of immigrants within the workplace. The review aimed to produce a sufficient knowledge-base to inform the development of recommendations to enhance professional social work practice and policy, inform employee assistance programs and policies, and provide recommendations for future research in this area.

The remainder of this paper is organized as follows. Section 2 describes the methodology used to conduct this systematic review and presents a cross-tabulation of the studies identified by the review. Section 3 presents a detailed description of the studies and offers an intuitive discussion on the findings. Finally, section 4 presents our conclusion, implications for the policy and practice, limitations of this review and suggestions for future research.

\section{$2.0 \quad$ Materials and methods}

In November of 2014, we conducted electronic searches in the following databases: Academic Search Complete, Academic One File, International Bibliography of the Social Sciences, SocINDEX with Full Text, Communication \& Mass Media Complete, PSYCHinfo, and Emerald Full Text. The following keywords / key word sets were used to search the literature: (1) linguistic diversity or language, (2) social integration (or social interaction or social inclusion), (3) immigrant (or immigrants or migrant or migrants or refugee or refugees or newcomer or newcomers), and (4) workplace (or organization or organisation). The electronic searches were repeated in January 2015. 
The inclusion criteria were: (1) peer-reviewed journal article, (2) published in English, (3) studies based on original data, (4) published after 2000, (5) studies focused on language related issues in workplace settings, (6) studies focused on the encounters of two or more language groups, (7) studies broadly focusing on role of language in social inclusion of immigrants. The exclusion criteria were: (1) psycholinguistics studies, (2) studies exclusively conducted on students or language learners, (3) studies focused on role of language in educational success of immigrants, and (4) studies focused on effect of language skills on immigrants' income.

The electronic search yielded 3188 abstracts. First, each abstract was reviewed to determine its suitability for inclusion. After removing the duplicate studies, a total of 48 abstracts met the inclusion criteria. At the second stage, the full text of these articles were retrieved and reviewed with application of the inclusion criteria. A total of nine articles were found suitable for inclusion in this review. In addition to the electronic searches, a manual search was performed in the reference lists of the final nine articles, producing an additional article. Ten articles comprised the dataset for this review. The following information was abstracted from each article: (1) author of the study and publication year, (2) country, (3) participants / sample size, (4) research approach / methodology, (5) focus of the study, and (6) key findings. The results of the review are provided in Table 1. To ensure a complete and transparent reporting, PRISMA ${ }^{1}$ checklist and flow diagram were followed in this systematic review.

\footnotetext{
1 PRISMA: Preferred Reporting Items for Systematic Reviews and Meta-Analyses. It is an evidence-based minimum set of items for reporting in systematic reviews and meta-analyses.
} 


\begin{tabular}{|c|c|c|c|c|c|c|}
\hline \multicolumn{7}{|c|}{ Table 1: Summary of studies } \\
\hline Study & $\begin{array}{l}\text { Country } \\
\text { of Study }\end{array}$ & Sample Size & $\begin{array}{l}\text { Type of } \\
\text { Study }\end{array}$ & Methodology & Focus of Study & Key findings \\
\hline $\begin{array}{l}\text { Akomolafe } \\
(2013)\end{array}$ & $\begin{array}{l}\text { United } \\
\text { States }\end{array}$ & $\begin{array}{l}1 \text { institution with high } \\
\text { number of immigrants }\end{array}$ & qualitative & case study & $\begin{array}{l}\text { accent discrimination and } \\
\text { equality of opportunity }\end{array}$ & $\begin{array}{l}\text { Foreign accent negatively affects upward mobility in the workplace } \\
\text { Unlike other forms of discrimination, accent discrimination gets the } \\
\text { least attention in public debates. }\end{array}$ \\
\hline $\begin{array}{l}\text { Bergman et } \\
\text { al. (2008) }\end{array}$ & $\begin{array}{l}\text { United } \\
\text { States }\end{array}$ & $\begin{array}{l}21 \text { Hispanic, Caucasian, } \\
\text { Hispanic Caucasian }(10 \\
\text { born in U. S. }+11 \text { born } \\
\text { outside) }\end{array}$ & qualitative & $\begin{array}{l}\text { grounded } \\
\text { theory }\end{array}$ & $\begin{array}{l}\text { effect of language on } \\
\text { workplace experiences }\end{array}$ & $\begin{array}{l}\text { Speaking Spanish in workplaces has more negative (exclusion, } \\
\text { harassment, discrimination) but also some positive (inclusion, } \\
\text { camaraderie) effects. Language plays an important role in the way } \\
\text { individuals are treated in the workplace. }\end{array}$ \\
\hline $\begin{array}{l}\text { Colic-Peiske } \\
\text { r \& Hlavac } \\
(2014)\end{array}$ & Australia & $\begin{array}{l}204 \text { (134 Anglo-Australian } \\
+106 \text { non-anglophone } \\
\text { Australians) }\end{array}$ & quantitative & $\begin{array}{l}\text { empirical } \\
\text { study }\end{array}$ & $\begin{array}{l}\text { social inclusion of } \\
\text { professionally educated } \\
\text { and employed } \\
\text { non-Anglophone } \\
\text { immigrants in Australia }\end{array}$ & $\begin{array}{l}\text { Both Anglophone Australians and non-Anglophone Australian } \\
\text { immigrants agreed that communication between the two groups is } \\
\text { minimally hindered by comprehension problems due to } \\
\text { foreign-accented speech and cultural differences. Although the } \\
\text { positive picture that emerges may reflect specific experiences and } \\
\text { attitudes of middle-class professionals and may not be } \\
\text { generalizable. Increased contact of the 'multicultural middle class } \\
\text { with its Anglo-Australian counterpart is likely to be a factor in } \\
\text { dissociating foreign accent and negative stereotyping. }\end{array}$ \\
\hline $\begin{array}{l}\text { Creese } \\
(2010)\end{array}$ & Canada & 38 sub-Saharan Africans & qualitative & $\begin{array}{l}\text { thematic } \\
\text { analysis }\end{array}$ & $\begin{array}{l}\text { accent discrimination } \\
\text { faced by English speaking } \\
\text { migrants }\end{array}$ & $\begin{array}{l}\text { Settlement entails ongoing struggles to assert linguistic competency } \\
\text { even for those who were fluent in English prior to migration. }\end{array}$ \\
\hline $\begin{array}{l}\text { Lønsmann } \\
(2014)\end{array}$ & Denmark & 70 (Danes + Others) & qualitative & $\begin{array}{l}\text { ethnographic } \\
\text { study }\end{array}$ & $\begin{array}{l}\text { linguistic and } \\
\text { social challenges that are } \\
\text { related to the diversity of } \\
\text { language competences } \\
\text { among employees in the } \\
\text { modern workplace }\end{array}$ & $\begin{array}{l}\text { The data have shown that language competence can be linked to } \\
\text { social exclusion. For the blue-collar workers with no English skills } \\
\text { as well as other Danes with limited English skills, their lack of } \\
\text { language competence means that they are excluded from obtaining } \\
\text { basic information at work, and they believe that their lack of } \\
\text { language competence prevents them from looking for a better job }\end{array}$ \\
\hline $\begin{array}{l}\text { Nelson } \\
(2014)\end{array}$ & Sweden & $\begin{array}{l}5 \text { (second language } \\
\text { speakers) }\end{array}$ & qualitative & $\begin{array}{l}\text { discourse } \\
\text { analysis / } \\
\text { ethnographic } \\
\text { study }\end{array}$ & $\begin{array}{l}\text { use of humor and } \\
\text { swearing in informal } \\
\text { workplace } \\
\text { communication }\end{array}$ & $\begin{array}{l}\text { Strategic use of communicative factors has a positive impact on the } \\
\text { social integration of second language speakers in their workplace. }\end{array}$ \\
\hline $\begin{array}{l}\text { Remennick } \\
(2004)\end{array}$ & Israel & $\begin{array}{l}25 \text { (13 Russian speaking } \\
\text { immigrants }+12 \text { Hebrew } \\
\text { speaking natives) }\end{array}$ & qualitative & $\begin{array}{l}\text { ethnographic } \\
\text { study }\end{array}$ & $\begin{array}{l}\text { everyday work relations } \\
\text { and inter-group attitudes }\end{array}$ & $\begin{array}{l}\text { Both groups diligently guard their social borders and separate } \\
\text { identities, and share similar critical opinions on each other's work } \\
\text { ethic and competence. Conflicts arise around the issues of } \\
\text { educational and work status gaps, relations with supervisors, and } \\
\text { language use. The continuing use of Russian by immigrant workers } \\
\text { is interpreted by Hebrew-speakers as a sign of their separatism and }\end{array}$ \\
\hline
\end{tabular}




\begin{tabular}{|c|c|c|c|c|c|c|}
\hline $\begin{array}{l}\text { Schaeffer \& } \\
\text { Bukenya } \\
(2010)\end{array}$ & Germany & $\begin{array}{l}2,023 \text { (406 Italians, } 395 \\
\text { Greeks, } 401 \text { Turks, } 409 \\
\text { Spaniards, } 412 \text { ethinic } \\
\text { Yugoslavs) }\end{array}$ & quantitative & $\begin{array}{l}\text { empirical } \\
\text { study }\end{array}$ & $\begin{array}{l}\text { assimilation of foreign } \\
\text { nationals }\end{array}$ & $\begin{array}{l}\text { Language is one of the most critical factors for determining } \\
\text { integration and assimilation at the workplace and in society. } \\
\text { Greater language skills are required for social assimilation, as } \\
\text { compared to economic assimilation. }\end{array}$ \\
\hline $\begin{array}{l}\text { Schulter } \\
(2010)\end{array}$ & Turkey & 21 (Kurdish immigrants) & qualitative & $\begin{array}{l}\text { thematic } \\
\text { analysis }\end{array}$ & $\begin{array}{l}\text { perceptions of immigrant } \\
\text { language appropriateness } \\
\text { in the workplace }\end{array}$ & $\begin{array}{l}\text { The study established a connection between language choice and } \\
\text { social mobility as well as social stigma. The participants attest to } \\
\text { speaking Kurdish only in private domains. }\end{array}$ \\
\hline $\begin{array}{l}\text { Tange \& } \\
\text { Lauring } \\
(2009)\end{array}$ & Denmark & $\begin{array}{l}82 \text { ( } 43 \text { Danish }+39 \text { other } \\
\text { nationalities }\end{array}$ & qualitative & $\begin{array}{l}\text { exploratory } \\
\text { study / } \\
\text { thematic } \\
\text { analysis }\end{array}$ & $\begin{array}{l}\text { implications of } \\
\text { communicative practices } \\
\text { for social interaction and } \\
\text { relationships within } \\
\text { multilingual workplaces }\end{array}$ & $\begin{array}{l}\text { The study identified that language diversity fuels the } \\
\text { communicative practices of language clustering and thin } \\
\text { communication resulting in a disorganized use of human resources. }\end{array}$ \\
\hline
\end{tabular}




\subsection{Results and discussion}

Out of 10 studies, one was published before 2005, five were published between 2006 and 2010, and four were published after 2010. Four studies were conducted in Europe, three in North America, one each in Australia, Turkey and Asia. Language combinations investigated in the studies were Hebrew - Russian, Turkish - Kurdish; Swedish - other languages; German - Italian / Greek / Turkish / Spanish / Serbo-Croatian; English (U. S.) other languages; Danish - other languages; English (U. S.) - Spanish (Hispanic); English (Australian) - other languages; English (Canadian) - sub-Saharan African languages (Commonwealth English); and Danish - other languages ${ }^{2}$.

Most studies were qualitative $(n=8)$; two studies used quantitative methods. Of the qualitative studies, there was a case study, a grounded theory study, ethnographic studies $(n=3)$, and thematic analysis studies $(n=3)$. The case study investigated accent discrimination in American academia which employs high number of immigrants. Accent discrimination was also the focus of a Canadian study, which analyzed the qualitative data thematically. Both quantitative studies and three qualitative studies-one grounded theory and two ethnographic studies - investigated the role of language in social integration or inclusion of foreigners or immigrants in the mainstream societies. The three remaining studies, two were thematic analysis and one was an ethnographic study, investigated the implications of communicative practices for social interaction and intergroup perceptions. Sample sizes of the qualitative studies ranged from five (Nelson, 2014) to 82 (Tange \& Lauring, 2009). The two quantitative studies had 204 (Colic-Peisker \& Hlavac, 2014) and 2023 participants (Schaeffer \& Bukenya, 2010). Studies in the review concerned on three key areas: (1) social integration or social inclusion/exclusion, (2) social interaction and inter-group perception, and (3) accent discrimination. In addition, some studies pointed out that racial discrimination and ethnicity based stereotyping also contribute to social exclusion of immigrants. Because race based issues were considered to be out of the scope of this review, they are discussed only briefly in this paper.

\subsection{Social integration and local language skills}

The most frequently investigated phenomenon in the studies included in the review was the role of language in social inclusion or exclusion. Five studies examined the influence of local language skills and communicative practices on the social integration of second language speakers of the local language. The participants in these studies were second language speakers of German, Swedish, English and Danish. Three of these studies had both native as well as second language speakers of the local languages. Bergman et al., (2008) studied native and second language speakers of Spanish and English, Lønsmann's study (2014) included native and second language speakers of Danish and English, and Colic-Peisker \& Hlavac (2014) had native and second language speakers of English. Four of these studies concluded that language plays an important role in social integration of second language speakers. One study examined the foreign accented speech of second language speakers (Colic-Peisker \& Hlavac, 2014).

In their empirical study, Schaeffer and Bukenya (2010) investigated the assimilation of foreign nationals in Germany and concluded that language is one of the most critical factors that determines the integration and assimilation of foreigners, not only at the workplace but also in society more broadly. In another study, Bergman et al. (2008) examined the workplace communicative practices of Hispanic employees in an American workplace. They found that language plays an important role in the way immigrants are treated in the workplace and concluded that Hispanic employees faced exclusion, harassment and discrimination if they spoke Spanish at the workplace. They also suggested that speaking Spanish appeared to mark the speaker as an outsider (Bergman et al., 2008). Similarly, Lønsmann's (2014) study of international employees, who were experts in their fields e.g. scientists, engineers, business managers or IT specialists, showed that a lack of or weak linguistic competence of the local language--Danish, lead to the social exclusion of immigrants in the workplace. Immigrant employees also reported lack of knowledge-sharing due to their lack of or weak Danish skills, and believed that they could not advance within the hierarchy of the organization (Lønsmann, 2014). Nelson's (2014) empirical study on the relationship between social integration and local language skills found that participants, who were second language speakers of Swedish, used their Swedish linguistic skills strategically to negotiate their integration in the workplace and in their immediate work group. The author found that certain communicative factors have a positive impact on the integration of local language speakers in the workplace and in their immediate work team. Nelson (2014) described her participants as proactive, who took communicative risks to fit-in.

\footnotetext{
${ }^{2}$ Local language precedes the hyphen in each language combination
} 
Finally, Colic-Peisker \& Hlavac (2014) studied Anglophone and non-Anglophone members of the Australian middle class. They did not take into account the English skills of non-Anglophone Australians, focusing solely on accents. The results, which were contrary to other studies included in this review, indicated an agreement between Anglophone and non-Anglophone participants that communication is minimally hindered by comprehension problems due to foreign-accented speech. The authors concluded that foreign accent does not matter in the social inclusion of non-Anglophone Australian middle class in workplace or social contexts

\subsection{Social interaction or intergroup perception and local language skills}

Three studies in this review examined the social interactions between local and second language speakers in workplace contexts (Remennick, 2004, Tange \& Lauring, 2009; Schulter, 2010). These studies also looked into the intergroup perceptions or attitudes between the two groups. Remennick (2004) examined the work relations between Russian speaking former Soviet immigrants and Hebrew speaking native Israelis and found that both groups maintain their social borders and separate identities by means of language. Both groups expressed critical opinions on each other's work ethics and competence. According to the Remennick (2004), the language use of Russian speaking immigrants triggered conflicts in the workplaces between the two groups, as it was seen by Hebrew speaking native Israelis as a sign of separatism and an anti-Israeli outlook. The study reported that often, due to a lack of or weak Hebrew competence, Russian speaking immigrants not only worked below their qualifications, on the lower tier of organizational ladder, but their promotions were also delayed (Remennick, 2004). Schulter (2010) examined the perception of the use of immigrant vs local language in workplace by Kurdish speaking migrants living in western Turkey. Schulter (2010) found that the use of Kurdish was highly socially stigmatized, which in turn, promoted a self-imposed Kurdish language ban not only in public work spaces but also in enclosed environments, where the communication between Kurdish workers was not subject to public scrutiny (Schulter, 2010).

Tange and Lauring (2009) examined cross cultural communication and social interaction within multilingual workplaces. The goal of the study was to provide a general picture of communicative practices within multilingual work environment in Denmark, where the corporate language was English. In this large qualitative study, the research sites were 14 culturally and linguistically diverse workplaces in Denmark. Roughly half of the participants were native speakers of Danish and half were native speakers of other languages. Only one participant had English as his/her native language. The study identified two communicative barriers-language clustering 3 and thin communication ${ }^{4}$ - that arise from the social use of language. The authors concluded that language diversity causes language clustering and thin communication. Thus, individuals who were fluent in the corporate language of the organization, engaged in the social bonding and formal and informal communications. However, individuals who lacked the competency or fluency in English found themselves isolated from information networks and decision making processes, which resulted in the emergence of language clusters (Tange \& Lauring, 2009). As a consequence of the fear of exposure of their weak English skills, which was believed to reflect badly on their professional competence, non-native speakers of English withdrew from socializing, small talks or informal exchanges. (Tange \& Lauring, 2009).

\subsection{Accent discrimination}

Two studies in this review examined the issue of accent discrimination faced by immigrants at workplaces (Akomolafe, 2013; Creese, 2010). Incidentally, both studies took place in North America. Creese (2010) studied the problem of accent discrimination in Canada, faced by English-speaking migrants from sub-Saharan Africa. Her thematic analysis indicated that the central problem faced by African migrants, particularly women, is the problem of accent discrimination. The study focused on the data collected through qualitative interviews with people from sub-Saharan African Commonwealth countries. Creese (2010) reported that accent discrimination in Canada results in systematic forms of inequality. Creese (2010) identified that the local accents of English in Canada are considered to be unaccented, standard, authoritative, and superior forms of English. Whereas the accents attached to people of color, from former British colonies, are defined as undesirable, foreign, problematic, and unintelligible thereby undermining the perception of competence of immigrants as potential employees, and influencing the power relations. Creese (2010) asserted that accent discrimination should be understood as a means of excluding and marginalizing immigrants. Similar conclusions were reached from Akomolafe's (2013) study whose objective was to establish a direct relationship between foreign accent and upward mobility in the American workplace. Using a case study of academia in United States, the study found

\footnotetext{
${ }^{3}$ Language clusters are the informal gatherings or alternative linguistic groups formed by the speakers of the same native language in a second language environment (Marschan-Piekkaria et al., 1999)

4 Thin communication could be defines as the withdrawal of organizational members from informal interaction performed in a non-native, corporate language (Tange \& Lauring, 2009)
} 
that academia employs a disproportionately large number of foreign-born nationals in the middle level ranks i.e. professors. However, the universities seldom consider these foreign accented professors for senior administrative level positions (Akomolafe, 2013). The study endeavored to establish that for foreign born, accented American professors, equality of opportunity is a pure myth. Akomolafe (2013) asserted that his case study is reflective of what goes on in other sectors of the society e.g. government, media, business, sports, entertainment etc.

This systematic review examined the effects of local language competence on social integration of immigrants within the workplace. For the purpose of this review, smooth social and professional assimilation, and the equality of opportunities for the immigrants were considered as the determining factors of their complete social integration in the workplace. Excluding one study, which focused solely on the 'foreign accent' of the immigrants and not on their overall local language skills, the findings of all other studies provide evidence that the lack of or weak local language skills negatively influence the complete integration of immigrants in the workplace contexts. The review suggests that immigrants' use of native language within the workplace can cause their social exclusion; whereas, immigrants' strategic use of second or local language can have a positive impact on their social integration within the workplace. The very fact that the research studies included in this review come from across the world, look into a variety of language combinations and are set up in different cultures contribute to the robustness of the findings.

Most studies in this review established a connection between the role of second language skills and workplace social integration. However, some studies also traced other factors such as racial discrimination and ethnicity based stereotyping as contributing to social exclusion of immigrants, particularly in case of those belonging to visible minority. For instance, Bergman et al. (2008) related weak local language skills to social exclusion, harassment and discrimination. But, they also suggested that appearance and ethnicity based maltreatment are also important to understand the phenomenon. Similarly, Creese (2010), asserted that questioning the linguistic skills of immigrants, particularly their accentedness, is nothing else but a means of "excluding and marginalizing immigrants of color without ever naming race or their immigrant status" (p. 310). The findings of Akomolafe's (2013) study are also congruent with those reported by Bergman et al. (2008) and Creese (2010) in that he upheld that it is highly likely that the foreign-born Americans face discrimination based on their national-origin. Through his research, Akomolafe (2013) raised an important question that if the accentedness of foreign-born Americans does not hinder them from getting doctorates from the top schools of United States, or from teaching their classes as professors, then why it should hinder them from reaching the pinnacle of their career.

Though Colic-Peisker and Hlavac (2014) came out with contradictory findings, it also had an underlying element of racial discrimination. Colic-Peisker and Hlavac (2014) suggested that in Australia, foreign accent is no longer stigmatized, as a foreign accent is increasingly becoming normalized in the linguistically diverse Australian society. Their study proposed that foreign accent is not looked down upon as an unwanted social marker by Australian middle class. This was the only study in this review that found no relation between local language skills and social inclusion of immigrants in the workplace. However, Colic-Peisker and Hlavac (2014) examined only the influence of foreign-accented speech on social inclusion, and their study involved only professionally educated participants belonging to the middle-class society. Colic-Peisker and Hlavac (2014) mentioned that they did not investigate the effect of racial visibility and embodied differences on social integration, and acknowledged that when they disaggregate their sample into Europeans and non-Europeans, they find a significant impact of race on the social inclusion of immigrants. This impact was also visible on the social inclusion of the Indigenous population of Australia, which is not linguistically but racially different than the majority population. Their data suggested that the perception of the accent may be influenced by the racial embodiment of the speaker; therefore, some accents were considered more desirable than others. Colic-Peisker and Hlavac (2014) remarked that their study sample was "highly educated and professionally employed and therefore in a crucial sense 'socially included' [who might have considered] occasional disturbances [...] as nonessential and not worth reporting" (p. 366). However, Colic-Peisker and Hlavac (2014) conclusion stand in contradiction to the findings of Akomolafe (2013), in which Akolomafe concluded that even highly educated professors face discrimination if they are born outside of the U.S. and they speak with a foreign accent.

One of the studies that directly addressed the issue of the influence of language skills on social integration in a linguistically diverse workplace was conducted by Tange and Lauring (2009). The study examined social interaction between locals and expatriates rather than immigrants. In any case, it was conducted on individuals who work in a different cultural and linguistic environment therefore this study was highly relevant for contributing to the understanding of diversity management in workplace contexts. Tange and Lauring (2009) identified "[second] language users' orientation of social interaction towards the members of their own speech community [which] represents an obstacle to cross-cultural communication" (p. 228). The study participants described the situations where they found that their organization's linguistic or cultural diversity had affected 
their work routines. The participants also commented on their experiences with diversity and its impact on communication. Although, the study respondents who belonged to the dominant language group considered language diversity as an asset to their organization, native speakers of other languages expressed their discomfort over how the linguistic majority formed an alternative linguistic group. Interestingly, Tange and Lauring (2009) noticed that several linguistic groups or language clusters existed within the research sites and employees preferred interaction with someone from their own linguistic group. Clearly, such communicative practices have implications for social integration within workplaces.

Lønsmann's (2014) study findings are congruent with those reported by Tange and Lauring (2009). In Lønsmann's (2014) study the second language speakers were international experts or expatriates as well as immigrants working in blue-collar jobs. Lønsmann's (2014) participants also linked their corporate or local language competence to their social exclusion. They believed that the lack of or weak local language not only prevented them from obtaining basic information at work but also excluded them from the job market. These claims were also supported by Schaeffer and Bukenya (2010), who found that language was a determining factor when it comes to social integration of immigrants at the workplace. Nelson's (2014) research was also somewhat consistent with the aforementioned studies because her study suggested that the second language should be used strategically to "foster good relations at work" and to "facilitate and consolidate integration in the workplace" (p. 173). This implies that Nelson (2014) also linked local language competence to workplace integration of immigrants.

Schulter's (2010) study also strongly supports the relation between language and social integration. Despite the fact that Schulter (2010) did not study international migrants in her research, she observed the same phenomenon in Turkey. Her Kurdish speaking participants, who had migrated from eastern and southeastern Turkey, to Turkish speaking Istanbul in western Turkey, also faced similar issues related to language use and social integration. Schulter (2010) examined the perceptions of Turkish vs. Kurdish language appropriateness in the workplace. Given the political background surrounding the usage of Kurdish language in Turkey, her participants reported a social stigma attached to the use of Kurdish language. Most of her participants attested to speaking only Turkish at work because they believed that speaking Kurdish in public domain leads to their social exclusion. Out of her 21 participants, only three claimed no restrictions on their choice of language at work and all three of these participants held managerial positions. Nevertheless, two of these participants reported minimal use of Kurdish as they felt speaking Kurdish in public domain might offend the Turkish people around them. Out of fear of social exclusion, Schulter's (2010) participants preferred speaking in Turkish even if they were talking to other Kurdish speaking individual.

Finally, Remennick's (2004) study also contributes to our understanding of the impact of immigrants' use of language on their social integration within the workplace. She reported that in Israel a vast immigrant population is the native speaker of Russian. However, a conversation in Russian between two or more Russian speaking employees is interpreted by Hebrew speakers as separatist and anti-Israeli, leading to social exclusion of Russian speaking immigrants, and creating situations of conflict. The findings of Remennick's (2004) study "endorse the primary role of language use as a key determinant of work relations in multicultural workplaces" (p. 66).

\subsection{Conclusion and policy implications}

This review summarized the current body of research on linguistic diversity in the workplace and social integration of immigrants. In immigrant receiving countries, where linguistic diversity is not exceptional, language creates various challenges. A most salient challenge is how to avoid marginalization for immigrants who lack the local language competence. The findings of this review inform professional social work practice and policy as well as employee assistance programs and policies. The findings enhance our understanding of the challenges of complete integration faced by the immigrants at the linguistically diverse workplaces of immigrant receiving countries. The review provides input to immigrant settlement services and programs that provide support to new immigrants. It also informs social workers who work with immigrants and advocate for them. In addition, the findings of this review have implications for organizations that are attempting to create welcoming and inclusive workplaces.

The studies included in this review suggest a robust relationship between local language competence of immigrants and their social integration within the workplace. However, the review could identify only a limited research in this area upon which to develop practice or policy recommendation related to social inclusion. Therefore, in future we require more research into how linguistic diversity is handled in the workplaces of immigrant receiving countries. Several studies found racial underpinnings in their findings, thus future research is warranted to investigate the relation between the acceptance of immigrant languages / accents within the 
workplace, and the ethno-cultural background of the immigrants. We require research to examine if the perception of immigrant language is hindered by ethnic stereotyping. The studies included in this review gave us an insight into the attitudes of the dominant society, towards immigrant languages and other aspects of diversity. However, it is important to know the language policies of the organizations and their effects on social integration. It is imperative to examine whether the societal values of immigrant receiving countries are expressed in the official and informal policies and practices of the organizations. Essentially, we need research to investigate how language issues related to diversity are handled in organizations.

\section{References}

Akomolafe, S. (2013). The invisible minority: Revisiting the debate on foreign-accented speakers and upward mobility in the workplace. Journal of Cultural Diversity, 20(1), 7-14.

Berger, P. L., \& Luckmann, T. (1966). The social construction of reality. New York: Double Day.

Bergman, M. E., Watrous-Rodriguez, K. M., \& Chalkley, K. M. (2008). Identity and language: Contributions to and consequences of speaking Spanish in the workplace. Hispanic Journal of Behavioral Sciences, 30(1), 40-68. http://dx.doi.org/10.1177/0739986307311255

Bourdieu, P. (1991). Language and symbolic power. Cambridge: Polity Press.

Bourdieu, P. (2004). Distinction: A social critique of the judgment of taste. London: Routledge.

Boyd, M. \& Cao, X. (2009). Immigrant language proficiency, earnings, and language policies. Canadian Studies in Population, 36(1-2), 63-86.

Charles, D., Gill, M. L., \& Scaltsas, T. (1994). Unity, identity, and explanation in Aristotle's metaphysics. Oxford: Clarendon Press.

Charles, M., \& Marschan-Piekkari, R. (2002). Language training for enhanced horizontal communication: A challenge for MNCs. Business Communication Quarterly, 65(2). 9-29. http://dx.doi.org/10.1177/108056990206500202

Chomsky, N. (1996). Language and problems of knowledge: The Managua lectures. Cambridge (Mass): The MIT Press.

Clegg, S. R. (1989). Frameworks of power. London: Sage Publications. http://dx.doi.org/10.4135/9781446279267

Colic-Peisker, V., \& Hlavac, J. (2014). Anglo- Australian and non- Anglophone middle classes: 'foreign accent' and social inclusion. Australian Journal of Social Issues, 49(3), 349-371.

Creese, G. (2010). Erasing English language competency: African migrants in Vancouver, Canada. Journal of International Migration \& Integration, 11(3), 295-313. http://dx.doi.org/10.1007/s12134-010-0139-3

Dhir, K. S., \& Góké-Paríolá, A. (2002). The case for language policies in multinational corporations. Corporate Communications: An International Journal, 7(4), 241-51. http://dx.doi.org/10.1108/13563280210449822

Dustmann, C. \& Fabbri, F. (2003). Language proficiency and labour market performance of immigrants in the UK. The Economic Journal, 113, 695-717. http://dx.doi.org/10.1111/1468-0297.t01-1-00151

Feely, A. J., \& Harzing, A. (2003). Language management in multinational companies. Cross Cultural Management: An International Journal, 10(2), 37-52. http://dx.doi.org/10.1108/13527600310797586

Gibson, J. W., \& Hodgetts, R. M. (1991). Organizational communication: A managerial perspective. New York: Harper Collins. http://dx.doi.org/10.1080/10919399109540165

Grünhage-Monetti, M., Halewijn, E., Holland, C., \& European Centre for Modern Languages. (2003). Odysseus: Second language at the workplace: Language needs of migrant workers: Organising language learning for the vocational-workplace context. Strasbourg: Council of Europe.

Lønsmann, D. (2014). Linguistic diversity in the international workplace: Language ideologies and processes of exclusion. Multilingua, 33(1/2), 89-116. http://dx.doi.org/10.1515/multi-2014-0005

Luo, Y., \& Shenkar, O. (2006). The multinational corporation as a multilingual community: Language and organization in a global context. Journal of International Business Studies, 37, 321-339. http://dx.doi.org/10.1057/palgrave.jibs.8400197

Marschan-Piekkari, R., Welch, D. E., \& Welch, L. S. (1999a). Adopting a common corporate language: IHRM implications. The International Journal of Human Resource Management, 10(3), 377-90. http://dx.doi.org/

$10.1080 / 095851999340387$

Marschan-Piekkari, R., Welch, D. E., \& Welch, L. S. (1999b). In the shadow: the impact of language on structure, power and communication in the multinational. International Business Review, 8, 421-40. http://dx.doi.org/10.1016/S0969-5931(99)00015-3

Nelson, M. (2014). 'You need help as usual, do you?': Joking and swearing for collegiality in a Swedish workplace. Multilingua, 33(1-2), 173-200. http://dx.doi.org/10.1515/multi-2014-0008

Remennick, L. (2004). Work relations between immigrants and old-timers in an Israeli organization: Social interactions and inter-group attitudes. International Journal of Comparative Sociology, 45(1/2), 45-71. http://dx.doi.org/10.1177/0020715204048310 
Sacks, O. W. (1989). Seeing voices: A journey into the world of the deaf. Berkeley: University of California Press.

Scaheffer, P. V., \& Bukenya, J. O. (2010). Assimilation of foreigners in former West Germany. International Migration, 52(4), 157-174. http://dx.doi.org/10.1111/j.1468-2435.2010.00617.x

Schulter, A. (2010). Kurdish voices in Istanbul workplaces. The International Journal of Diversity in Organisations, Communities and Nations, 10(4), 127-140.

Shields, M. A., \& Wheatley-Price S. (2002). The English language fluency and occupational success of ethnic minority immigrant men living in English metropolitan areas. Journal of Population Economics, 15(1), 137160. http://dx.doi.org/10.1007/PL00003836

Tange, H., \& Lauring J. (2009). Language management and social interaction within the multilingual workplace. Journal of Communication Management, 13(3), 218-232. http://dx.doi.org/10.1108/13632540910976671

Vaara, E., Tienari, J., Piekkari, R., \& Säntti, R. (2005). Language and the circuits of power in a merging multinational corporation. Journal of Management Studies, 42(3), 595-623. http://dx.doi.org/10.1111/j.1467-6486.2005.00510.x

Von Glinow, M. A. Y. (1988). The new professionals: Managing today's high-tech employees. Cambridge, Mass: Ballinger Pub. Co.

Wittgenstein, L., Ogden, C. K., \& Russell, B. (1922). Tractatus logico-philosophicus. London: Kegan Paul. Retrieved from http://www.gutenberg.org/files/5740/5740-pdf. 